\title{
OCCURRENCE OF FUNGI ON SOME DETERIORATED ANCIENT EGYPTIAN MATERIALS AND THEIR CONTROLLING BY ECOFRIENDLY PRODUCTS
}

\author{
Mansour, M. ${ }^{1} \&$ Ahmed, H. ${ }^{1}$ \\ ${ }^{1}$ Lecturer, Conservation dept., Faculty of Archaeology, Cairo University, Egypt. \\ E-mail: maisamansour_40@yahoo.com
}

\begin{abstract}
Tuna el-Gabel's excavations represent a model of the Egyptian excavation's nature, in terms of variations and fluctuations in degrees of humidity and temperature throughout the year. The excavations contain various types of antiquities which are made from different organic and inorganic materials belong to different Egyptian eras, especially the Ptolemaic era. These conditions have an impact on finding a certain kind of fungus damage, which passively affects the antiquities in the excavations. This research presents a practical study meant to determine and define the fungi existed in the organic and inorganic antiquities in Tuna el- Gabel's excavations. Six samples were taken from different Archaeological objects from which 24 fungal strains representing 10 genera were isolated. The identified fungal isolates ; Aspergillus niger, Aspergillus terreus, Aspergillus flavus, Aspergillus humicola, Fusarium moniliforme, Chaetomium indicum, Helminthosporium sativum, Alternaria tenuis and Rhizopus sp. Comparative study using different types of fungicides and natural products on the isolated fungal species suggested that the complete inhibition of tested fungal species was performed with lower concentration of clove oil, which is harmless to humans, $(0.75 \%)$ than the fungicides.
\end{abstract}

Keywords: Excavation, Fungi, Bio-deterioration, Clove oil, Sterilization

\section{Introduction}

The Excavation of tuna el-Gabel, located to the west of the ancient city of Thermopolis Magna has been the first and for a longer period the only ibis (and baboon) animal cemetery during the reign of Pharaoh Pasmetkhos (664-619 BC). The total number of ibises deposited in the vast subterranean network of galleries clearly surpasses one million individuals, implying that on average some 15000 birds had been placed each year in the galleries by the cult servants. These include domestic (cattle, sheep, dogs, cats) a wild mammals (shrews, monkeys, ichneumons, wild cats, gazelles etc), reptiles (crocodiles, snakes) and fishes, as well as a large variety of birds (herons, storks, geese, ducks, birds of prey, owls etc). Today the archaeological zone of Tuna el Gable is located in a flat desert landscape to the west of the cultivated Nile valley, $5 \mathrm{~km}$ to the south of the modern village, opposite a broad desert wadi, through which a track once led to the Bahariya oasis. The settlement, which developed after $1000 \mathrm{BC}$, was located at the southern tip of a now extinct lake, known from geographic maps as the Hod Tuna [1]., as shown in fig. (1-a). A summary from around the world of the fungi found on heritage objects to reveals many species in common. Four genera 
(Alternaria, Aspergillus, Cladosporium, and Penicililum) are found on all objects and in the air worldwide. This supports a common origin of the fungi contaminating heritage objects: coming from airborne conidia during fabrication or during use [2] [3]. The environmental factors, which influence conidial germination and the subsequent hyphal growth, are the same. These factors are many and they include water relationships, temperature, oxygen and carbon dioxide, $\mathrm{pH}$, light and toxic characteristics of the substrate [4]. It was reported that among the most suitable conditions for the growth of fungi are: temperature between $24-30{ }^{\circ} \mathrm{C}, \mathrm{RH}$ of 65 $80 \%$, and $\mathrm{pH}$ slightly acid, i.e. about 5.5 [5] [6]. No published studies of the identification of fungi or fungal Tuna El-Gabel excavation have provided

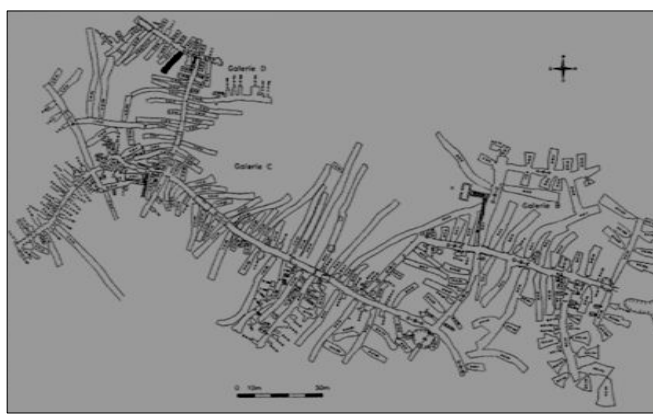
deterioration on ancient objects in the

details of their nature or degradation factors. The Colonization of microorganisms on monuments and biodeterioration are usually linked to environmental conditions. The most significant parameters affecting microbial growth are represented by physical factors, mainly moisture, temperature, and light, as well as by the chemical nature of the substratum. Microorganisms always present in nature and affect our daily life directly or indirectly. Subterranean animal necropolis at Tuna el-Gabel, Middle Egypt was shown in fig. (1-b \& c). This study aims at the monitoring of the fungi of different objects (organic and inorganic material) in excavation and preservation of this material from fungal biodeterioration by using safe fungicide was a national goal in this work.

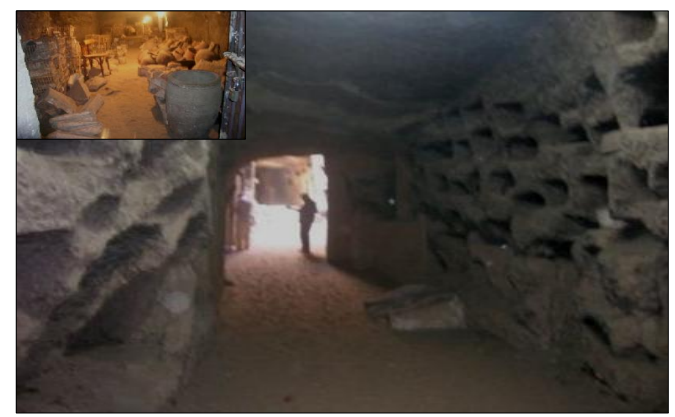

Figure (1) The subterranean animal necropolis at Tuna el-Gebel, Middle Egypt.

\section{Materials and Methods}

\subsection{Materials}

Three essential materials were chosen and used as follow: 1. Clove oil Dianthus caryophyllus, code 9025.100 , supplied by AEFRED BECHT GMBH [7]. 2. Teldor ${ }^{\circledR} 500$ SC Fungicide supplied by Bayer CropScience,

\subsection{Site description and sampling}

The study samples were taken from the different material found on the Tomb (wood, bone, resin, macrophages limestone, baskets, tomb roof, mummy dust, ground tomb and, pottery). Samples

\subsection{Cultivation, isolation and characterization of fungi}

Fungi were isolated from sample material; the following nutrient media (PDA agar) were prepared: 200g. Potato
Australia [8]. 3. Tecto® Flowable SC Fungicide, Code A10466C, Syngenta Crop Protection Pty Limited, 2-4 Lyonpark Road, MacquariePark, NSW 2113, Australia [9].

were different in terms of deterioration and discoloration. Samples were taken for mycological analyses by swabbing surfaces with sterile cotton swabs. The sample were then stored at $4^{\circ} \mathrm{C}$.

extract, 20g. Agar and 20g. dextrose and completed to one liter by tap water. Sample wood was cultivation on Petri 
dish containing PDA medium and incubated on $25-30{ }^{\circ} \mathrm{C}$., after 7 days colonies were isolated, purified by using the hyphal tip and / or single spore techniques. A total of 24 fungal strains were isolated representing 10 genera.
Special attention was given to the colonies, which were gained by the direct transfer of biofilm fragments. Colonies of isolated fungi on PDA medium were shown in fig. (2).
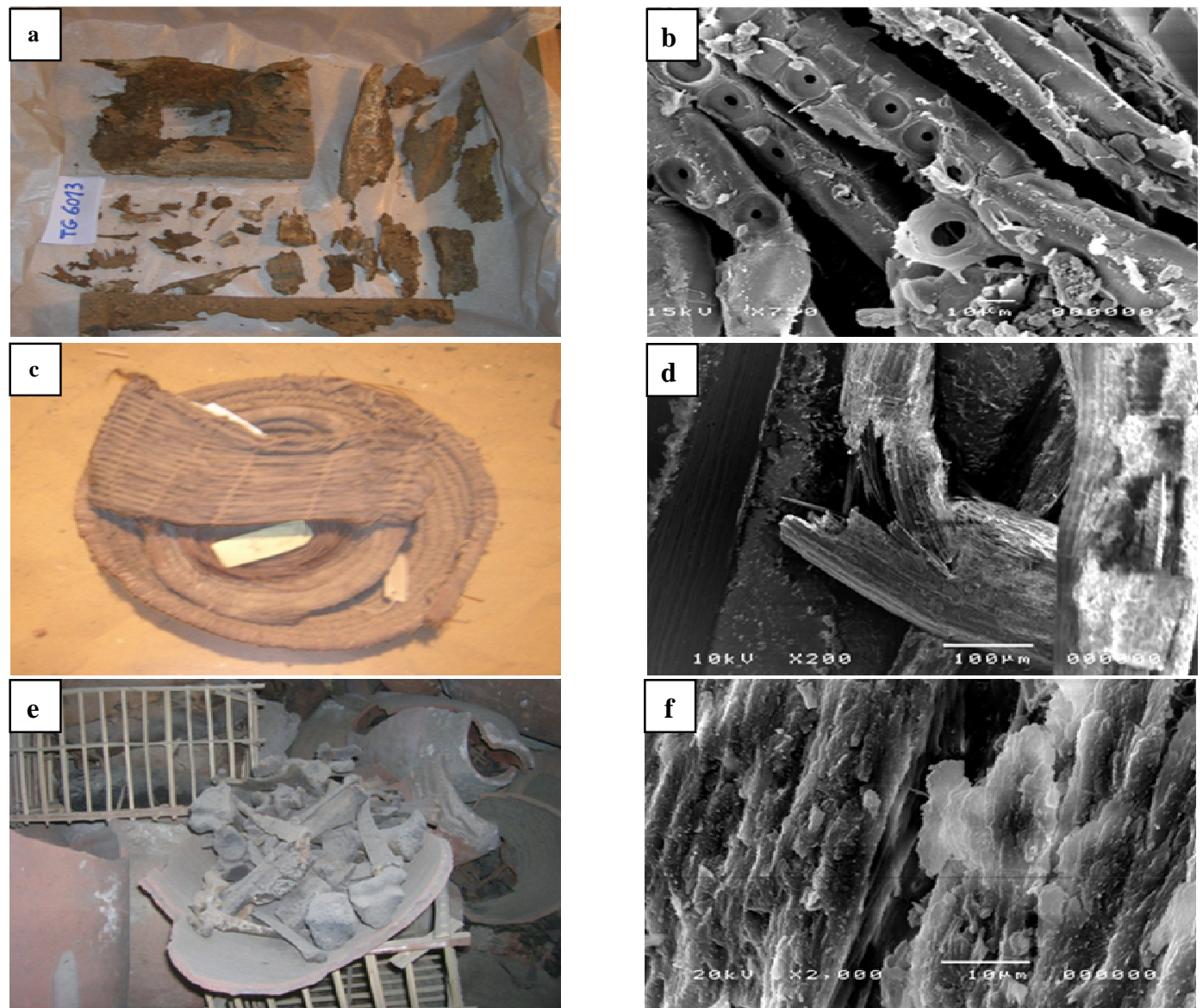

Figure (2) Some photos and SEM photomicrograhs showing a the contaminated and decayed wood in tuna excavation $\underline{\mathbf{b}}$ decayed wood that show wood structure and the effect of biological damage on wood. $\underline{\mathbf{c}}$ ethnographic object in tuna excavation. $\underline{\mathbf{d}}$ the damage aspects. $\underline{\mathbf{e}}$ the contaminated bone in tuna excavation. $\underline{\mathbf{f}}$ structure of contaminated bone.

\subsection{Visual and morphological features of fungal deterioration}

Tow optical methods have been used to study the fungal deterioration on the objects: * The visual investigation: the initial visual assessment revealed that the objects have indicated a poor conservation condition due to the fungal deterioration. This step is very important to study fungal deterioration aspects on the surface of different objects.

\subsection{Identification}

The isolates were studied under the light microscope and identified to genera level according to their morphological characteristics. Samples
*Scanning Electron Microscope (SEM): the fungal deterioration study was carried out by using SEM model - a FEI Quanta 200 ESEM FEG scanning electron microscope was used to study the change of surface morphology and particle size of the fungal deterioration ground samples [10].

for scanning electron microscopy (SEM) were air-dried, coated with gold (Balzers Union SCD 030); the samples were suspended in physiological 
solution and blended for 1 min using a

Techno, Eksel, Belgium) [11] [12].

\section{Stomacher Lab-blender (L.E.D.}

\subsection{Using clove oils on the fungal linear growth}

Clove oil was used at concentrations of $0,0.125,0.25,0.5$, 0.75 and $1 \%$ using micropipettes. Each oil concentration plus one $\mathrm{ml}$ of tween 80 were added to the autoclaved PDA medium immediately before solidification and pouring into the plates. The next day after pouring medium, Clove oil was tested for their inhibitory effect on linear growth of ten fungi i.e Aspergillus niger, Aspergillus terreus, Aspergillus flavus, Aspergillus humicola, Fusarium moniliforme, Chaetomium indicum, Helminthosporium sativum, Alternaria tenuis, Rhizopus sp. and Acrothecium apicale. Plates were inoculated each with a7 mm disc taken from 7-10 days old cultures of a given fungus.

\subsection{Two types of fungicides on the fungal linear growth}

Nine concentrations i.e. $0,5,10$, 25, 50, 100, 250, 500 and $1000 \mathrm{ppm}$ of each of fungicides i.e. Tecto (Thiabendazole) $50 \% \mathrm{SC}$ and Teldor ${ }^{\circledR}$ 500 (Fenhexamid) $50 \% \mathrm{SC}$ were tested for their inhibitory effect on linear growth of the tested fungi that caused deterioration of some archeological objects using the method described by Horsfall, 1956 [13]. Desired amount from a tested fungicide (from stock solution) were added aseptically to known amount of sterilized PDA medium immediately before pouring in

\section{Results}

The results of the study are divided into two essential parts which include the following points: $\mathbf{1}^{\text {st }}$ one is to identify the types of fungi found in the different organic and inorganic archeological objects in Tuna El-Gabel excavations. $\mathbf{2}^{\text {nd }}$ is to a comparative study using different types of fungicides. Furthermore, using and developing an effective, a non-toxic alternative control technique and easy procedure such as natural extracts of some flowers to eliminate biodeterioration of art collections on a large scale. The existed fungi recognized in wood objects are Aspergillus niger, Aspergillus flavus, Aspergillus humicola and Rhizopussp. While the most important fungi which have been found in the bone are plates. After solidification, the plates were inoculated, each with a disc (7 $\mathrm{mm}$ diameter) taken from the 4-daysold culture (on plain agar) of a tested pathogen. Four plates, for each particular concentration from each fungicide, were used for each pathogen. All plates were incubated at $\left(26{ }^{\circ} \mathrm{C}\right)$ and the linear growth was observed and recorded daily .The experiment was terminated when the plates in the control treatment were filled with mycelia growth.

Aspergillus niger, Aspergillus terres, Aspergillus flavus, Aspergillus humicola, Fusarium moniliforme, Alternaria tenuis and Acrothecium apicale. Moreover, through evaluating SEM photomicrographs it appears that the most important fungi are Aspergillus niger, Aspergillus terreus, Aspergillus flavus and Aspergillus humicola. On the other hand, it could be observed that the fungi found in pottery objects are Aspergillus niger, Aspergillus humicola, Helminthosporium sativu and Rhizopus sp. Furthermore, the results proved that the resin in the stone coffin had been affected through high environmental contamination by the fungi species such as Aspergillus niger, Aspergillus humicola and Chaetomium indicum. Finally the results shows the 
basket was affected by two types of fungi such as Aspergillus niger, Aspergillus humicola, these fungal types are listed in tab (1), figs. (3) \& different types of fungicides proved that there are controlling on the fungal linear growth in the investigated samples as listed in $\operatorname{tab}_{\mathrm{s}}(2),(3) \&(4)$.

(4). Finally, it could be said that using

Table (1) List of fungi isolated from different deteriorated objects in Tuna el- Gableexcavation.

\begin{tabular}{|c|c|c|c|c|c|c|}
\hline Fungi & Wood & Bone & Resin & $\begin{array}{c}\text { Sarcophagus } \\
\text { (limestone) }\end{array}$ & Baskets & $\begin{array}{c}\text { Pottery } \\
\text { coffin }\end{array}$ \\
\hline Aspergillus niger & $*$ & $*$ & $*$ & $*$ & $*$ & $*$ \\
\hline Aspergillus terreus & & $*$ & - & $*$ & - & - \\
\hline Aspergillus flavus & $*$ & $*$ & - & $*$ & - & - \\
\hline Aspergillus humicola & $*$ & $*$ & $*$ & $*$ & $*$ & $*$ \\
\hline Fusarium moniliforme & - & $*$ & - & - & - & - \\
\hline Chaetomium sp. & - & - & $*$ & - & - & - \\
\hline Helminthosporium sativum & - & - & - & - & $*$ & - \\
\hline Alternaria tenuis & - & $*$ & - & - & - & - \\
\hline Rhizopus sp & $*$ & - & - & - & - & $*$ \\
\hline Acrothecium apicale & - & - & - & - & - & - \\
\hline
\end{tabular}

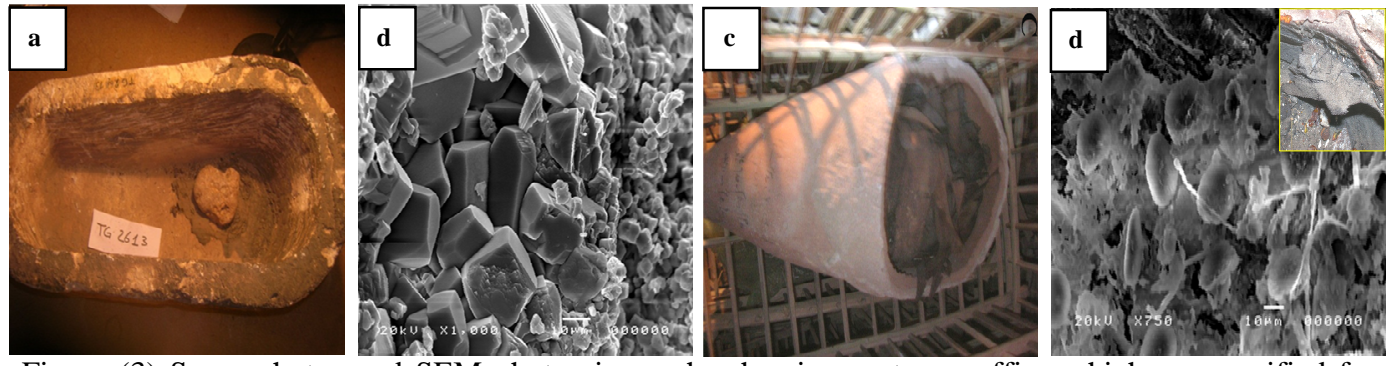

Figure (3) Some photos and SEM photomicrograhs showing a stone coffins which are specified for saving stuffed birds, $\underline{\mathbf{b}}$ pottery coffins which are specified for saving stuffed birds, $\underline{\mathbf{c}}$ risen included with wrapped linen fabrics that used in mummification of animal body, $\underline{\mathbf{d}}$ wrapped linen became a dark color
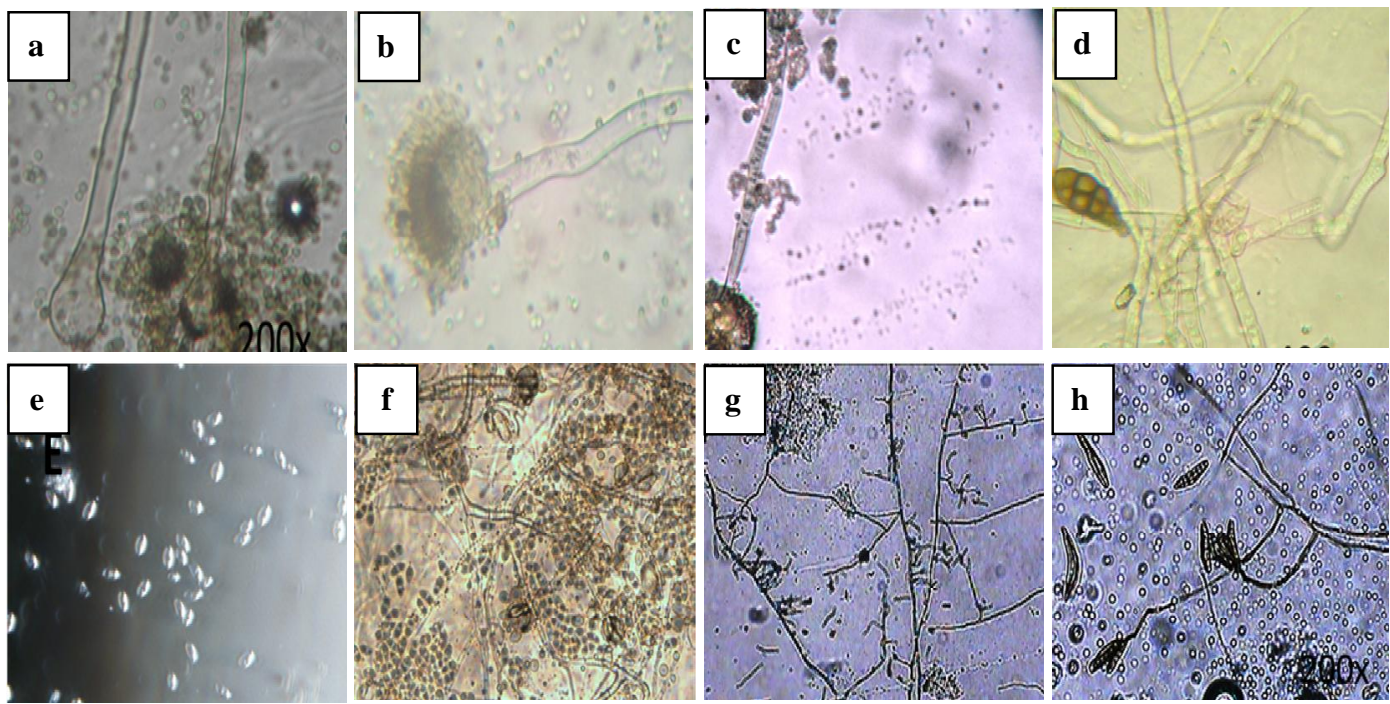

Figure (4) Microscopic images of different kind of fungi affected historical sample from Tuna elGebel excavation a Aspergillus terrus, $\underline{\mathbf{b}}$ Aspergillus niger, $\underline{\mathbf{c}}$ Aspergillus flavus, $\underline{\mathbf{d}}$ Alternaria tenus, $\underline{\mathbf{e}}$ Chaetomium indicum, $\underline{\mathbf{f}}$ Fusarium moniliforme, $\mathbf{g}$ Helminthosporium sativum and $\underline{\mathbf{h}}$ 
Table (2) Effect of different concentrations of some clove oil on linear growth of the tested fungi (in $\mathrm{mm}$ )

\begin{tabular}{|l|c|c|c|c|c|c|c|c|c|}
\hline \multicolumn{1}{|c|}{ Fungi } & \multicolumn{8}{|c|}{ Concentrations of clove oil } \\
\hline Aspergillus niger & Control & $\mathbf{0 . 1 2 5}$ & $\mathbf{0 . 2 5}$ & $\mathbf{0 . 5 0}$ & $\mathbf{0 . 7 5}$ & $\mathbf{1 . 0}$ & $\mathbf{2 . 5}$ & $\mathbf{5 . 0}$ \\
\hline Aspergillus terreus & 90 & 0.0 & 0.0 & 0.0 & 0.0 & 0.0 & 0.0 & 0.0 \\
\hline Aspergillus flaves & 90 & 0.0 & 0.0 & 0.0 & 0.0 & 0.0 & 0.0 & 0.0 \\
\hline Aspergillus humicola & 90 & 0.0 & 0.0 & 0.0 & 0.0 & 0.0 & 0.0 & 0.0 \\
\hline Fusarium moniliforme & 90 & 0.0 & 0.0 & 0.0 & 0.0 & 0.0 & 0.0 & 0.0 \\
\hline Chaetomium sp. & 90 & 22 & 18 & 11 & 0.0 & 0.0 & 0.0 & 0.0 \\
\hline Helminthosporium sativum & 90 & 17 & 0.0 & 0.0 & 0.0 & 0.0 & 0.0 & 0.0 \\
\hline Alternaria tenus & 90 & 16 & 13 & 12 & 0.0 & 0.0 & 0.0 & 0.0 \\
\hline Rhizopus sp. & 90 & 13 & 0.0 & 0.0 & 0.0 & 0.0 & 0.0 & 0.0 \\
\hline Acrothecium apicale & 90 & 0.0 & 0.0 & 0.0 & 0.0 & 0.0 & 0.0 & 0.0 \\
\hline
\end{tabular}

Table (3) Effect of different concentrationsof Tecto fungicide on linear growth of different fungi (in mm).

\begin{tabular}{|c|c|c|c|c|c|c|c|c|c|c|c|}
\hline \multirow[b]{2}{*}{$\begin{array}{l}\text { Conc. } \\
\text { (ppm) }\end{array}$} & \multicolumn{11}{|c|}{ Linear growth in mm. of tested fungi after Tecto fungicide application } \\
\hline & $\begin{array}{l}\text { Asp. } \\
\text { Nig. }\end{array}$ & $\begin{array}{l}\text { Asp. } \\
\text { Terr }\end{array}$ & $\begin{array}{l}\text { Asp. } \\
\text { Flav }\end{array}$ & $\begin{array}{c}\text { Asp. } \\
\text { Hum. }\end{array}$ & $\begin{array}{c}\text { Fus. } \\
\text { Moni } \\
\text {. }\end{array}$ & $\begin{array}{c}\text { Chaet } \\
\text {. } \\
\text { sp. }\end{array}$ & $\begin{array}{c}\text { Hel. } \\
\text { sat. }\end{array}$ & $\begin{array}{l}\text { Alt. } \\
\text { tenu } \\
\text { s }\end{array}$ & $\begin{array}{c}\text { Rhiz } \\
\text { sp. }\end{array}$ & $\begin{array}{l}\text { Acro } \\
\text { apic. }\end{array}$ & $\begin{array}{c}\text { Mea } \\
\mathbf{n}\end{array}$ \\
\hline $\mathbf{0}$ & 90.0 & 90.0 & 90.0 & 90.0 & 90.0 & 90.0 & 90.0 & 90.0 & 90.0 & 90.0 & 90.0 \\
\hline 5 & 45.0 & 28.0 & 16.0 & 38.0 & 40.0 & 76.0 & 87.0 & 85.0 & 54.0 & 76.0 & 54.5 \\
\hline 10 & 42.0 & 24.0 & 0.7 & 15.0 & 16.0 & 64.0 & 81.0 & 78.0 & 33.0 & 64.0 & 41.8 \\
\hline 25 & 38.0 & 19.0 & 0.0 & 0.7 & 0.7 & 49.0 & 73.0 & 70.0 & 14.0 & 59.0 & 32.3 \\
\hline 50 & 34.0 & 14.0 & 0.0 & 0.0 & 0.0 & 38.0 & 64.0 & 59.0 & 13.0 & 51.0 & 27.3 \\
\hline 100 & 26.0 & 0.0 & 0.0 & 0 & 0.0 & 21.0 & 23.0 & 24.0 & 10.0 & 45.0 & 14.9 \\
\hline 250 & 0.0 & 0.0 & 0.0 & 0.0 & 0.0 & 11.0 & 12.0 & 18.0 & 0.0 & 26.0 & 6.7 \\
\hline 500 & 0.0 & 0.0 & 0.0 & 0.0 & 0.0 & 0.0 & 0.0 & 0.0 & 0.0 & 0.0 & 0.0 \\
\hline 1000 & 0.0 & 0.0 & 0.0 & 0.0 & 0.0 & 0.0 & 0.0 & 0.0 & 0.0 & 0.0 & 0.0 \\
\hline Mean & 30.6 & 19.4 & 11.9 & 16.0 & 16.3 & 38.8 & 47.8 & 47.1 & 23.8 & 45.7 & \\
\hline \multirow{2}{*}{\multicolumn{2}{|c|}{$\begin{array}{l}\text { L.S.D. at } 0.05 \\
\text { for: }\end{array}$}} & \multicolumn{4}{|c|}{ Fungi (F) } & \multicolumn{3}{|c|}{ Concentrations (C) } & \multicolumn{3}{|c|}{$\mathbf{F} \times \mathbf{C}$} \\
\hline & & \multicolumn{4}{|c|}{0.76} & \multicolumn{3}{|c|}{0.83} & \multicolumn{3}{|c|}{2.64} \\
\hline
\end{tabular}

Table (4) Effect of different concentrationsof Teldor fungicide on linear growth of different fungi(in mm).

Conc. Linear growth in $\mathbf{m m}$. of tested fungi after Teldor fungicide application

\begin{tabular}{|c|c|c|c|c|c|c|c|c|c|c|c|}
\hline (ppm) & $\begin{array}{l}\text { Asp. } \\
\text { Nig. }\end{array}$ & $\begin{array}{l}\text { Asp. } \\
\text { Terr. }\end{array}$ & $\begin{array}{l}\text { Asp. } \\
\text { Flav. }\end{array}$ & $\begin{array}{l}\text { Asp. } \\
\text { Hum. }\end{array}$ & $\begin{array}{l}\text { Fus. } \\
\text { Moni. }\end{array}$ & $\begin{array}{l}\text { Chaet. } \\
\text { sp. }\end{array}$ & $\begin{array}{l}\text { Hel. } \\
\text { sat. }\end{array}$ & $\begin{array}{c}\text { Alt. } \\
\text { tenus }\end{array}$ & $\begin{array}{l}\text { Rhiz. } \\
\text { sp. }\end{array}$ & Acro. & Mean \\
\hline 0 & 90.0 & 90.0 & 90.0 & 90.0 & 90.0 & 90.0 & 90.0 & 90.0 & 90.0 & 90.0 & 90.0 \\
\hline 5 & 90.0 & 73.0 & 90.0 & 80.0 & 90.0 & 42.0 & 45.0 & 53.0 & 74.0 & 90.0 & 72.7 \\
\hline 10 & 90.0 & 52.0 & 90.0 & 69.0 & 84.0 & 39.0 & 41.0 & 43.0 & 58.0 & 90.0 & 65.6 \\
\hline 25 & 81.0 & 41.0 & 90.0 & 55.0 & 75.0 & 30.0 & 37.0 & 39.0 & 38.0 & 90.0 & 57.6 \\
\hline 50 & 69.0 & 35.0 & 90.0 & 48.0 & 63.0 & 26.0 & 30.0 & 32.0 & 34.0 & 90.0 & 51.7 \\
\hline 100 & 57.0 & 21.0 & 90.0 & 40.0 & 51.0 & 22.0 & 23.0 & 28.0 & 21.0 & 89.0 & 44.2 \\
\hline 250 & 38.0 & 17.0 & 51.0 & 28.0 & 49.0 & 18.0 & 20.0 & 25.0 & 8.0 & 85.0 & 33.9 \\
\hline 500 & 30.0 & 11.0 & 16.0 & 19.0 & 40.0 & 13.0 & 16.0 & 20.0 & 2.0 & 76.0 & 24.3 \\
\hline 1000 & 26.0 & 0.0 & 0.0 & 16.0 & 38.0 & 0.0 & 11.0 & 14.0 & 0.0 & 68.0 & 17.3 \\
\hline Mean & 63.4 & 37.8 & 67.4 & 49.4 & 64.4 & 31.1 & 34.8 & 38.2 & 36.1 & 85.3 & \\
\hline \multirow{2}{*}{\multicolumn{2}{|c|}{$\begin{array}{l}\text { L.S.D. at } 0.05 \\
\text { for: }\end{array}$}} & \multicolumn{4}{|c|}{ Fungi (F) } & \multicolumn{3}{|c|}{ Concentrations $(\mathrm{C})$} & \multicolumn{3}{|c|}{$\mathbf{F} \times \mathbf{C}$} \\
\hline & & \multicolumn{4}{|c|}{2.34} & \multicolumn{3}{|c|}{2.57} & \multicolumn{3}{|c|}{6.83} \\
\hline
\end{tabular}




\section{Discussion}

\subsection{Identification of fungi in Tuna el-Gabel}

Egypt has different climatic regions that contribute to the development of many species of fungi. This research is seeking to identify the fungi on different Egyptian excavation sites and present a non-toxic alternative control technique to eliminate bio-deterioration with the protection of the health of the users and the environment. Thus, the study has started this work on Tuna El-Gabel excavation site. Tuna El-Gabel excavations are distinguished by containing many pieces of wood, which are represented in coffins and statues. Initial visual and SEM studies show that the wooden objects are in moderate condition, others are in deteriorated state and they suffered severe biological damage, which may be in form of powder. Historical wood, either movable or immovable, is subjected to degradation induced by diverse living organisms. Fungi are among the most active microorganisms in these processes. One can see that the fungi used the organic support itself as nutrients. The damage that appeared in the studied object due to the heterotrophic nutrition of fungi as shown in fig. (2). The action of fungi on cellulosic support is common for cellulolytic fungi that perform external digestion through cellulose complex enzymes that degrade the cellulose in basic molecules of glucose which are then absorbed by the fungus. However, there are other groups beside the cellulolytic fungi that attack the other components of the support as well. Taking the wood for example, we know that besides cellulose it is constituted by lignin which is far more difficult to digest by the fungus, but even then there are several species that can achieve it successfully. Lignin is an amorphous polymer formed by the random combination of various phenols and acids that leads to a three-dimensional structure. The effects of some fungi on cellulose and lignin are known as rot. Three types of rot can be highlighted according to the residual state of the wood fiber after having been attacked by certain fungi [14] [15]. The existed fungi are recognized, which are as the following: Aspergillus niger, Aspergillus flavus, Aspergillus humicola and Rhizopussp, tab. (1) fig. (4). Fungi deteriorate organic material in respect to the aesthetic and degradation aspect, although these are not independent as the aesthetic degradation is sometimes due to the external manifestation of the chemical transformation process that the support undergoes. Some other times, it is simply a matter of stains or other alterations easy to solve, although this occurs in just a few cases [14] [15] Bones in the excavations belong to stuffed birds and animals. Through examination, it appears clearly that the most important fungi which have been found in the bone are as the following: Aspergillus niger, Aspergillus terres, Aspergillus flavus, Aspergillus humicola, Fusarium moniliforme, Alternaria tenuis and Acrothecium apicale [16]. Biodeterioration of inorganic supports is radically different because the fungi are heterotrophic organisms they do not use the supports for nutrition but they do alter them deeply with synthesis products from their own metabolism, such as inorganic and organic acids. The latter can produce chelation and form complexes with metallic cations, which are obtained from the support. From the biological point of view, stone is an extreme environment poor of nutrients, with enormous changes of humidity, with mechanical erosion due to wind and rain and high doses of UV radiation. Nevertheless, stone is inhabited by fungi and other microorganisms in all climate regions of the earth [17] [18]. Epilithic fungi-living on the rock - and endolithic fungi - living inside of pores and fissures - fungi play a major role in the weathering of monuments made of rock [19] [20]. Sarcophagus (limestone), fig. (3), which specified for saving stuffed birds, showing the coffin from 
which we took the sample. The other figure represents SEM examination; it appears that the most important fungi are as the following: Aspergillus niger, Aspergillus terreus, Aspergillus flavus and Aspergillus humicola. These fungi are responsible, along with other chemical and biological factors, for the formation of black crusts due to the melanin in their hyphae. The hyphae of the fungus can penetrate the limestone calcite crystals previously dissolved by enzymes. In other words, Fungi produce and excrete organic acids that change of stone $\mathrm{pH}$. Acids may produce chelation, among which the oxalic acid that induces a large corrosion of primary minerals and the complete decomposition of ironbased components of clay [21] [22] [23]. Initial visual and SEM study of different pottery show that the object is in moderate condition. Pottery coffins which are specified for saving stuffed birds, which represents photographic. In the case of inorganic supports, they are transformed by several metabolites which are excreted and that may react with the support in different ways. The other figure represents SEM examination. It appears that the Observed fungi were Aspergillus niger, Aspergillus humicola, Helminthosporium sativu and Rhizopus $s p$. Fungi are responsible for serious biodeterioration problems in composite of organic materials [24]. Resin is adjacent to the wrappings, which are the outer layer of the mummies. Fig. (3) shows the resin in the stone coffin. Classical methods were used to identify the microorganisms. The results showed that there to be high environmental contamination by the fungi Aspergillus niger, Aspergillus humicola and Chaetomium indicum. Visual and SEM study of baskets show that the object is in moderate condition. The study shows two types of fungi which have been found on the basket such as Aspergillus niger, Aspergillus humicola. The study also focuses on the identity of fungi in the environment around the objects.

\subsection{Effect of Clove oils concentrations on the fungal linear growth}

It is clear from results listed in tab. (2) that the fungi growing in organic materials are difficult to eliminate. Many toxic products, including biocides, have been used to prevent bio-deterioration in materials and the environment. However, these procedures are usually harmful to people and to the objects they are intending to de-infest. Some type of chemical fungicide cause change in archeological object. It was mentioned that thy mol makes change on naturallyaged watercolors, zinc white and Arabic gum as media [16] [25] [26]. Gamma and laser irradiation were used as nontoxic fumigation, but these methods need different and complex equipment

\subsection{Effect of Tecto fungicide concentrations on the fungal linear growth}

It is clear from results in Table. 3 that, linear growth of different tested fungi was significantly reduced by most tested concentrations of Tecto fungicide compared with control. Reduction in that are not available in the excavation sites [10]. Alternative methods based on the use of non-toxic treatment e.g., natural extracts, from some natural flowers as antifungal, have recently been under investigation. Clove oil has been applied on the isolated mould colonization from the Excavation of tuna el-Gabel. The data revealed that significant decrease in the growth of all isolated fungal species with progression stopped in the lowest concentration. Growth species of Aspergilluswas inhibited in the first concentration (0.125). The highest inhibition zone was (0.50) for Fusarium moniliforme and Helminthosporium sativum.

linear growth was increased by increasing concentration of most tested fungicides from 5.0 up to $1000 \mathrm{ppm}$. In general, the mycelial growth of all tested fungi was completely stopped at 
500 and 1000 ppm. Aspergillus flavus was the most sensitive fungi against Tecto fungicide and their mycelial growth recorded the highest reduction of linear growth followed by Aspergillus humicola , Fusarium moniliforme, Aspergillus terreus and Rhizopus sp., while, Helminthosporium sativum and Alternaria tenuis were the most tolerant fungi and their mycelial growth recorded the lowest reduction of linear growth followed by Acrothecium apicale, however, Aspergillus niger and Chaetomium sp. were intermediate tolerant fungi. Mycelial growth of

\subsection{Effect of Teldor $® 500$ fungicide on the fungal linear growth}

Data presented in tab. (4) show the effect of different concentrations of Teldor ${ }^{\circledR} 500$ fungicide on linear growth of different tested fungi and indicated that, the efficiency of Teldor (B) 500 fungicide at most concentrations was weakly or moderately effective against linear growth of most tested fungi or most tested fungi were more tolerant against different concentrations of Teldor ${ }^{\circledR} 500$ fungicide especially at the least concentrations. Chaetomium $s p$ was the most sensitive fungus against different concentrations of Teldor ${ }^{\circledR} 500$ fungicide followed by Rhizopus sp, Helminthosporium sativum, Aspergillus terreus and Alternaria tenuis, respectively. On the other hand, Acrothecium apicale was different tested fungi was completely stopped at different concentrations in this study. Linear growth of Aspergillus flavus was completely stopped at 25 ppm but Aspergillus humicola and Fusarium moniliforme was completely stopped at $50 \mathrm{ppm}$ whereas, linear growth of Aspergillus terres was completely stopped at $100 \mathrm{ppm}$ and linear growth of Aspergillus niger and Rhizopus $s p$ was completely stopped at $250 \mathrm{ppm}$, the rest fungi, however, their linear growth was completely stopped at $500 \mathrm{ppm}$.

\section{Conclusion}

This study provides the first identification of fungi on Tuna el-Gabel excavations. The study found the following types of fungi in the different objects in Tuna el-Gabel excavations: Aspergillus niger, Aspergillus terreus Aspergillus flavus, Aspergillus humicola, Fusarium moniliforme, Chaetomium sp. Helminthosporium sativum, Alternaria tenuis, Rhizopussp, Acrothecium apicale. The use of clove oil is considered a useful and safe for the sterilization of different archeological objects and closed excavation sites. This study will help preserve the archaeological objects from bio-deterioration damage at Tuna el-Gabel excavations. This study will help save the archaeologists health at Tuna elGabel excavations. An alternative is the use of clove oil, a promising treatment in the preservation filed. The obtained results confirmed that clove oil treatment of different archeological objects in Tuna El-Gabel excavations is very efficient. This method has brought a powerful way to save archeological objects being damaged by fungi. Using this method for the sterilization of the cemetery and all objects in the cemetery is considered a non-harmful effect on the human health. Furthermore, it does not have a detrimental effect residue as in the case of pesticides. For sterilization of the cemetery, we can use clove oil $0.75 \mathrm{ml}$ in $100 \mathrm{ml}(\mathrm{v}: \mathrm{v})$ distilled water with tween to separate the oil in water. The amount of the sterilization solution depends on the size of the cemetery in cubic meters. Then the cemetery to be left closed for 24 hours. Also the study could be concluded that, Tecto fungicide was more effective for 
reducing linear growth of the tested fungi more Teldor ${ }^{\circledR} 500$ fungicide at different concentrations especially at the highest concentrations. As well as some tested fungi were more sensitive to one fungicide and tolerant to the other for example, Aspergillus flavus and Fusarium moniliforme were more sensitive against Tecto fungicide but were more tolerant to Teldor ${ }^{\circledR} 500 ;$ on the other hand, Chaetomium sp., Helminthosporium sativum and Alternaria tenuis were more tolerant against Tecto fungicide but were more sensitive to Teldor ${ }^{\circledR} 500$ in compared to the other fungi. This study, undoubtedly, will be followed by other studies to identify the fungi in different excavations sites with different climatic environment in Egypt.

\section{Reference}

[1] Drisch, A., Kessler, D., Steinnmann, F., Berteaux, V., \& Peters, J. (2005). Mummified, deified and buried at hermopolis magna the sacred birds from tuna El-Gabel, Middle Egypt, Egypt and the Levant. Int. J. for Egyptian archaeology and related disciplines, Vol. XV, pp: 203-244.

[2] Eckhardt, F. (1980). Microbial degradation of silicates. Release of cations from aluminosilicate minerals by yeast and filamentous fungi, in: Oxley, T., Allsopp, D. \& Becker, G., (eds.) Biodeterioration, Proc $4^{\text {th }}$ Int. symp., Berlin, Pitman, London, Vol. 107-116

[3] Florian, M. (1997). Heritage eaters, insects \& fungi in heritage collections, James \& James Ltd, London.

[4] Florian, M. (2004). Fungal facts, solving fungal problems in Heritage collections, Archetype Publication Ltd., London.

[5] Kowalik, R. (1980). Microbiodeterioration of library materials, Part II. Restaurator, Vol. 4, pp: 61-112.

[6] Torre, M., Gomez-Alarcon, G., Melgarejo, P., \& Saiz-Jimenez, C. (1991). Fungi in weathered sandstone from Salamanca cathedral, Spain. Science of the total Environment, Vol. 107, pp: $159-168$

[7] http://www.becht-online.de., Nov 28, 2011

[8]http://www.bayercropscience.com.au/c s/products/productdetails.asp?id=201, June 26, 2012

[9]http://www.syngenta.com/country/au /en/products/Pages/label.aspx, April 14,2012

[10] Geweely, N. (2006) Non-toxic fumigation and alternative control techniques against fungal coloniz- ation for preserving archaeological oil painting. Int. J. Botany, Vol. 2, pp: 353-362.

[11] Kouvelies, V., Zare, R., Bride, P. \& Typas, M. (1999). Differentiation of mitochondrial subgroups in the Verticilliumlecanii species complex. Letters in Applied Microbiology, Vol. 28, pp: 263-268

[12] Mansour, M. (2007). Studies on protection and preservation of wood archaeological furniture against mould fungi, PhD thesis, Faculty of Agriculture, Cairo Univ., Egypt

[13] Horsfall, J. (1956). Principles of fungicidal action chronica, Bot. Co., Mass, USA. 279.

[14] Caneva, G., Nugari, M., \& Salvadori, O. (1991). Biology in the conservation of works of art, ICCROM, Rome, Italy.

[15] Arroyo, I. (2009). The Role of fungi in the deterioration of movable and immovable cultural heritage, econservation magazine, Vol. 9, pp: 40-50.

[16] Perfect, J., Klotman, M., Gilbert, C., Cenise, D., Rosner, G., Wathleen, K., \& Peters, W. (1992). Prophylactic intravenous amphoteric in B in neutropenic autologous bone marrow transplant recipients. $J$. Infectious diseases, Vol. 165, pp: 891-897.

[17] Sterflinger, K. (2005). Black yeasts and meristematic fungi: ecology, diversity and identification, in: Rosa, C., Gabor, P. (eds.), Yeast handbook. Biodiversity and Ecophysiology of Yeasts, Vol. 1. Springer, New York, pp: 501-514.

[18] Selbmann, L., de Hoog, G., Mazzaglia, A., Friedmann, E., \& 
Onofri, S. (2005). Fungi at the edge of life: cryptoendolithic black fungi from the Antarctic desert, in: de Hogg, G. (ed.) Fungi of the Antarctic: evolution under extreme conditions, Studies in mycology, Vol. 51, pp: 1-32.

[19] Gadd, G. (2007). Biogeochemical transformations of rocks, minerals, metals and radio nuclides by fungi, bioweathering and bioremediation, Mycological Research, Vol. pp: 111, 3-49.

[20] Scheerer, S., Ortega-Morales, O., \& Galarde, C. (2009). Microbial deterioration of stone monumentsan updated overview. Advances in Microbiology, Vol. 66, pp: 97-139.

[21] Carlyle, L. (1987) Biodeterioration of constructional, in Morton, L. (ed.), British nineteenth-century oil painting instruction books: a survey of their recommendations for vehicles, pp. 17-39.

[22] Petersen, K., Kuroczkin, K., Strzelczyk, B., \& Krumbein, W. (1988). Distribution and effects of fungi on and in sandstones. Biodeterioration, Vol. 7, pp: 123128

[23] Monte, M., Sabbioni, C., \& Tapia, G. (1987). The origin of calcium oxalates on historical buildings, monuments and natural outcrops. Science of total Environment, Vol.67, pp: 17-39

[24] Valentin, N. (2003). Microbial contamination in museum collections: Organic materials, in: Saiz- Jimenez, C. (ed.) Molecular Biology and Cultural Heritage, Swets \& Zeitlinger Publishers, Netherlands, pp: 85-91

[25] Hall I. (1997). The effects of Thymol on paper, pigments, and media. Abby Newsletter 21. http://cool.conservationus.org/byorg/abbey/an/an21/an21-3/an21-308.html, 08May-2011

[26] Bjordal, C. \& Nilsson, T. (2001). Observation on microbial growth during conservation treatment of waterlogged archaeological wood. Studies in Conservation, Vol. 46, pp: 211-220. 